\title{
The effect of NAG-thiazoline on morphology and surface hydrophobicity of Escherichia coli
}

\author{
Christopher W. Reid ${ }^{a}$, Neil T. Blackburn ${ }^{b, 1}$, Anthony J. Clarke ${ }^{a, b, *}$ \\ ${ }^{a}$ Guelph-Waterloo Centre for Graduate Work in Chemistry and Biochemistry University of Guelph, Guelph, Ont., Canada N1G 2 W1 \\ ${ }^{\mathrm{b}}$ Department of Microbiology, University of Guelph, Guelph, Ont., Canada N1G 2W1
}

Received 19 January 2004; received in revised form 30 March 2004; accepted 31 March 2004

First published online 15 April 2004

\begin{abstract}
The $\beta$-hexosaminidase inhibitor and structural analog of the putative oxazolium reaction intermediate of lytic transglycosylases, $N$-acetylglucosamine thiazoline (NAG-thiazoline), was synthesized in $46 \%$ overall yield and tested as an inhibitor of Escherichia coli growth. NAG-thiazoline, at concentrations up to $1 \mathrm{mg} / \mathrm{ml}$, was not found to affect the viability of $E$. coli DH5 $\alpha$. However, the compound did induce morphological changes to the cells. Growth of cells in the presence of NAG-thiazoline caused an apparent inhibition of the biosynthesis of the cylindrical regions of the cells such that they became much shorter in length. The surface of these shorter cells was found to be much less hydrophobic compared to untreated cells as determined by the bacterial adhesion to hydrocarbon (BATH) assay. In addition, the co-administration of NAG-thiazoline with $1.7 \times$ MIC concentrations of ampicillin prevented cell lysis suggesting that the compound inhibited autolytic enzymes, in particular the lytic transglycosylases.
\end{abstract}

(C) 2004 Federation of European Microbiological Societies. Published by Elsevier B.V. All rights reserved.

Keywords: Escherichia coli; Morphology; NAG-thiazoline; Lytic transglycosylase; Penicillin-induced lysis; Autolysin

\section{Introduction}

The generally accepted model for the biosynthesis of peptidoglycan in Escherichia coli invokes enzyme complexes comprised of both transferases, a collection of penicillin-binding proteins (PBPs), and the lytic transglycosylases (LTs) (recently reviewed by Young [1]). The high-molecular weight PBPs catalyse the incorporation of newly synthesized and translocated peptidoglycan precursor molecule, Lipid II, into the existing sacculus at sites made available through the action of the LTs.

Abbreviations: GlcNAc, $N$-acetylglucosamine; MurNAc, $N$-acetylmuramic acid; NAG-thiazoline, $N$-acetylglucosamine-thiazoline; LT, lytic transglycosylase; PBP, penicillin-binding protein; SEM, scanning electron microscopy.

${ }^{*}$ Corresponding author. Tel.: +1-519-824-4120; fax: +1-519-8371802.

E-mail address: aclarke@uoguelph.ca (A.J. Clarke).

${ }^{1}$ Present address: Dade Behring Inc., 700 GBC Drive, Newark, DE 19714.
Inhibition of the transglycosylase or transpeptidase activities of the PBPs by moenomycin and the $\beta$-lactam antibiotics, respectively, leads to autolysis through the continued action of the LTs (reviewed in [2]). In addition, mutant strains deficient in either of the two classes of enzymes are characterized by significantly altered cell morphologies [1,3].

While much effort has been made to understand the function and mechanism of action of the PBPs with the aim to extend their usefulness as a target for antibacterial therapy, the LTs have attracted considerably less attention [4]. LTs function to cleave the same bond in peptidoglycan as the lysozymes, specifically the $\beta$ $(1 \rightarrow 4)$-glycosidic bond between the MurNAc and GlcNAc residues [5,6]. However, the LTs are catalytically distinct from the hydrolytic lysozymes because they are not hydrolases but cleave peptidoglycan with the concomitant formation of 1,6-anhydro-MurNAc residues (Fig. 1) [5].

LTs appear to be ubiquitous in the eubacteria that produce peptidoglycan (viz., all but the cell wall-less 

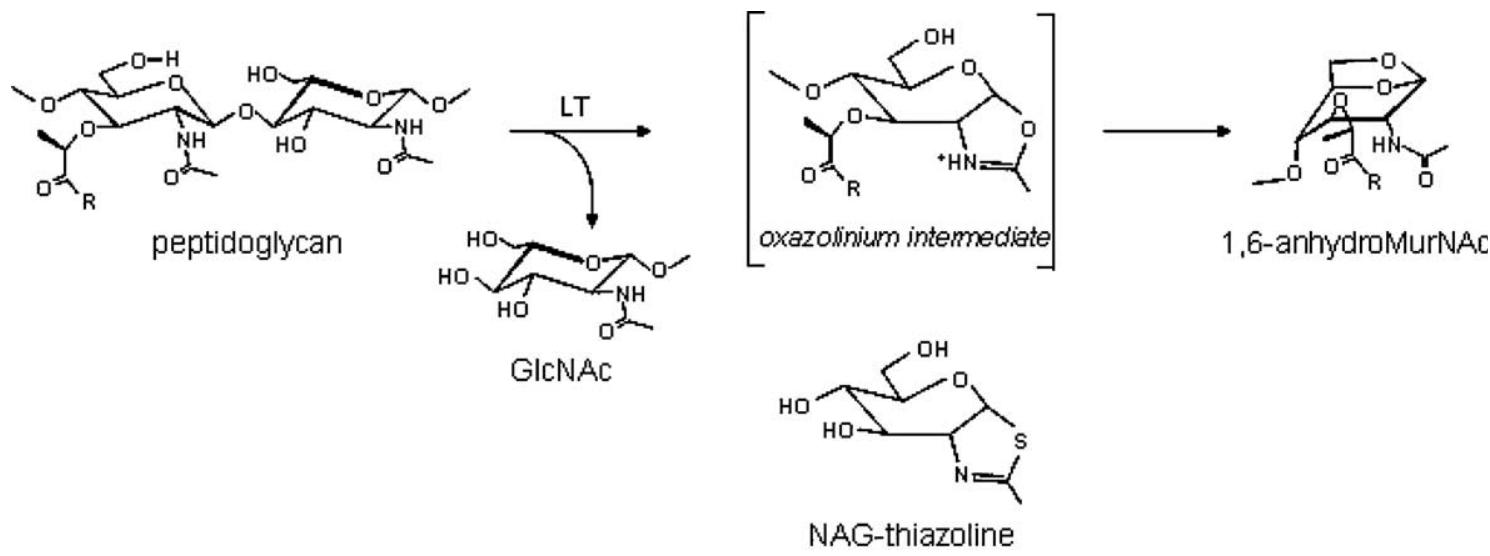

Fig. 1. Proposed reaction pathway of lytic transglycosylases (LT) and structure of NAG-thiazoline, an analogue of the oxazolium intermediate. R denotes the stem peptide of muramoyl residues involved in cross-linking of the glycan strands of peptidoglycan which are comprised of alternating GlcNAc and MurNAc residues.

mycoplasmas), and even in some lytic bacteriophages [7]. Given the apparent importance of these enzymes to the growth of the bacteria, the search for inhibitors of the LTs may prove to be valuable for the development of a new class of antibiotics with broad specificity. Based on both X-ray crystallographic and inhibition studies with bulgecin [8-10], it has been suggested that the LTs use substrate-assisted catalysis which proceeds through the formation of an oxazolium intermediate (Fig. 1) involving the muramyl residue at the site of cleavage in peptidoglycan. Recent investigations in our laboratory [11] have shown that purified LTs are inhibited by the $\beta$ hexosaminidase inhibitor and structural analog of the putative oxazolium intermediate, $N$-acetylglucosamine thiazoline (NAG-thiazoline) [12,13] (Fig. 1). In this study, we show that NAG-thiazoline causes changes to both morphology and cell surface hydrophobicity in growing $E$. coli cells, while also inhibiting $\beta$-lactam-induced autolysis.

\section{Materials and methods}

\subsection{Synthesis of NAG-thiazoline}

NAG-Thiazoline was prepared in $46 \%$ overall yield from peracetylated GlcNAc by treatment with Lawesson's reagent according to the procedure of Knapp et al. [13] with modifications. Thus, a solution of $1.03 \mathrm{~g}$ (2.66 mmol) of 2-acetamido-2-deoxy-1,3,4,6-tetra- $O$-acetyl- $\beta$ D-glucopyranose (Toronto Research Chemicals, Toronto, Ont.) in $10 \mathrm{ml}$ of dry toluene was treated with $0.68 \mathrm{~g}(1.68 \mathrm{mmol})$ of Lawesson's reagent (Sigma-Aldrich, St. Loius, MO), and the reaction mixture was heated to $60^{\circ} \mathrm{C}$ for $1.5 \mathrm{~h}$. The reaction mixture was then cooled to room temperature, washed with $\mathrm{H}_{2} \mathrm{O}$, dried over anhydrous $\mathrm{Na}_{2} \mathrm{SO}_{4}$, and concentrated. The resulting yellow syrup containing the crude thiazoline triace- tate was chromatographed on silica gel with ethyl acetate/hexane (7:1) as the solvent to give $0.42 \mathrm{~g}(46 \%)$ of purified peracetate.

A portion of the thiazoline triacetate $(0.42 \mathrm{~g})$ was treated with $0.2 \mathrm{M}$ methanolic sodium methoxide (10 ml) with stirring for $10 \mathrm{~min}$. After de-ionization with Bio-Rad 50W-X4 ( $\mathrm{H}^{+}$form; Bio-Rad Laboratories) cation-exchange resin, the reaction mixture was filtered and the filtrate was concentrated to give $0.27 \mathrm{~g}$ NAGthiazoline as a hygroscopic brownish solid. Purity and identity to the known NAG-thiazoline [13] was confirmed by TLC and NMR analysis. $R_{\mathrm{f}} 0.21$ (2:1:1:1 ethyl acetate/isopropanol/ $\mathrm{H}_{2} \mathrm{O} /$ acetic acid); ${ }^{1} \mathrm{H}$ NMR (400 $\left.\mathrm{MHz}, \mathrm{CD}_{3} \mathrm{OD}\right) \delta 6.37(\mathrm{~d}, 1 \mathrm{H}, J=7.0 \mathrm{~Hz}, \mathrm{H}-1), 5.60(\mathrm{~d}$, $0.1 \mathrm{H}, J=4.7 \mathrm{~Hz}$, residual GlcNAc $\mathrm{H}-1) 4.30(\mathrm{~m}, 1 \mathrm{H}$, $\mathrm{H}-2), 4.19(\mathrm{t}, 1 \mathrm{H}, J=4.0 \mathrm{~Hz}, \mathrm{H}-3), 3.78(\mathrm{dd}, 1 \mathrm{H}$, $\left.J=2.6,12 \mathrm{~Hz}, \mathrm{H}-6^{1}\right), 3.65(\mathrm{dd}, 1 \mathrm{H}, J=6.1,12 \mathrm{~Hz}, \mathrm{H}-$ 6), $3.62(\mathrm{ddd}, 1 \mathrm{H}, J=1.0,3.8,9.1 \mathrm{~Hz}, \mathrm{H}-4), 3.28$ (m, $1 \mathrm{H}, \mathrm{H}-5), 2.22\left(\mathrm{~d}, 3 \mathrm{H}, J=1.6 \mathrm{~Hz}\right.$, Thiazoline $\left.\mathrm{CH}_{3}\right) \cdot{ }^{13} \mathrm{C}$ NMR $\left(100 \mathrm{MHz}, \mathrm{CD}_{3} \mathrm{OD}\right) \delta 170.0(\mathrm{SC}=\mathrm{N}), 90.80$, $80.65,76.40,74.23,71.43,63.45,24.25$.

\subsection{Growth studies}

Growth of E. coli DH5a (Clonetech) cultures in the presence and absence of NAG-thiazoline was examined by culturing one colony in Luria-Bertani (LB) broth ( $1 \%$ tryptone peptone, $1 \% \mathrm{NaCl}, 0.5 \%$ yeast extract) at $37{ }^{\circ} \mathrm{C}$ with shaking. After $16 \mathrm{~h}$, a $1 / 50$ dilution of the culture was performed in triplicate into fresh LB broth containing NAG-thiazoline and growth was monitored turbidometrically $\left(\mathrm{OD}_{600}\right)$. Identical dilutions of the starter culture were inoculated into fresh LB broth alone to serve as controls.

In other experiments to examine the effect of NAGthiazoline on penicillin-induced autolysis, cultures of $E$. coli DH5 $\alpha$ were grown in LB broth at $37{ }^{\circ} \mathrm{C}$ to a cell density of $\mathrm{OD}_{600}$ of 0.18 (early exponential phase) and 
divided into three aliquots. Each aliquot was then supplemented with either nothing (to serve as controls), 5 $\mu \mathrm{g} / \mathrm{ml}(1.7 \times$ MIC) ampicillin, or $5 \mu \mathrm{g} / \mathrm{ml}$ ampicillin and $300 \mu \mathrm{g} / \mathrm{ml} \mathrm{NAG-thiazoline.} \mathrm{Subsequent} \mathrm{growth} \mathrm{at} 37^{\circ} \mathrm{C}$ was monitored turbidometrically for $5 \mathrm{~h}$ while samples were withdrawn periodically for microscopic examination.

\subsection{Morphological effect of NAG-thiazoline on $\mathrm{E}$. coli}

Phase contrast microscopy of unstained wet mounts of cells was conducted using Nomarski optics on a Leica microscope with differential interference contrast. Images were captured and then processed with Adobe Photoshop software.

For scanning electron microscopy, cells were harvested from $1 \mathrm{ml}$ samples of cultures by centrifugation at $8000 \mathrm{~g}$ for $10 \mathrm{~min}$ at $4{ }^{\circ} \mathrm{C}$. The bacterial cell pellet was washed in phosphate buffered saline to remove any residual broth. The pellet was then suspended in $70 \mathrm{mM}$ Sorensen's phosphate, $\mathrm{pH}$ 6.8, placed on a $0.2 \mu \mathrm{m}$ polycarbonate membrane filter (Poetics Corp. Livermore, CA), and fixed with $2 \%$ gluteraldehyde in phosphate-buffered saline for $1 \mathrm{~h}$ and post-fixed with $\mathrm{OsO}_{4}$. The samples were then rinsed in several changes of buffer, dehydrated through a series of ethanol washes, critical point dried (Ladd Industries) using carbon dioxide, and sputter coated with $20 \mathrm{~nm}$ of gold/palladium in a Hummer VII sputter coater (Anatech Corp. Alexandria, VA). To visualize the organisms, the filters were scanned using a Hitachi S-570 SEM (Tokyo, Japan), and images were collected directly from the SEM using Quartz PCI software (Quartz Imaging Corp. Vancouver, BC).

\subsection{Affect of NAG-thiazoline on LPS profile of $\mathrm{E}$. coli}

Cultures of E. coli DH5 $\alpha$ grown for $6 \mathrm{~h}$ (late exponential phase) in LB containing 0 or $600 \mu \mathrm{g} / \mathrm{ml}$ NAG-thiazoline (each in triplicate) were harvested by centrifugation $\left(6000 \mathrm{~g}, 10 \mathrm{~min}, 4^{\circ} \mathrm{C}\right)$ and the cells were resuspended in $100 \mu \mathrm{l}$ of NuPAGE ${ }^{\circledR}$ (Invitrogen Life Technologies Inc.) sample buffer for analysis of their LPS profiles [14]. After incubation at $100{ }^{\circ} \mathrm{C}$ for $10 \mathrm{~min}$, $50 \mu \mathrm{g}$ of Proteinase $\mathrm{K}$ was added and incubated at $60^{\circ} \mathrm{C}$ for $1 \mathrm{~h}$. Samples were then boiled at $100{ }^{\circ} \mathrm{C}$ for $10 \mathrm{~min}$ and diluted $1 / 10$ before loading onto a NuPAGE® 4 $12 \%$ gradient electrophoresis gel. Samples were subjected to electrophoresis for $80 \mathrm{~min}$ at $120 \mathrm{~V}$ and the LPS was detected by silver staining.

\subsection{Cell-surface hydrophobicity assay}

Surface hydrophobicity of cells grown in the presence and absence of NAG-thiazoline was assessed using the bacterial adhesion to hydrocarbon (BATH) assay of
Rosenberg et al. [15]. Cells grown to late exponential phase in LB broth containing $0,100,300$, or $600 \mu \mathrm{g} / \mathrm{ml}$ of NAG-thiazoline were harvested by centrifugation and washed with $3 \mathrm{ml}$ of $150 \mathrm{mM}$ phosphate buffer, $\mathrm{pH}$ 7.1 containing $30 \mathrm{mM}$ urea and $0.8 \mathrm{mM} \mathrm{MgSO}_{4}$. Triplicate samples of the washed cells were resuspended in the same buffer to an $\mathrm{OD}_{400}$ of 1.0, transferred to glass test tubes, and treated with $0.1 \mathrm{ml}$ hexadecane. Following incubation for $15 \mathrm{~min}$ at $37^{\circ} \mathrm{C}$ with shaking, the samples were vortexed for $2 \mathrm{~min}$ and the phases were allowed to separate for $10 \mathrm{~min}$. The $\mathrm{OD}_{400}$ of each of the aqueous phases was measured and expressed as a percentage of the difference between the adhesion to the glass and adhesion to hexadecane.

\section{Results and discussion}

\subsection{Growth inhibition studies}

The addition of up to $600 \mu \mathrm{g} / \mathrm{ml} \mathrm{NAG-thiazoline} \mathrm{did}$ not affect $E$. coli cultures grown in LB broth as compared to cultures supplemented with equal concentrations of GlcNAc, the parent compound of NAGthiazoline (data not shown). To further examine for any inhibitory effect of NAG-thiazoline on cell growth, determination of its minimum inhibitory concentration was attempted. Thus, doubling dilutions of the compound were added to LB broth and growth was monitored turbidometrically following inoculation and incubation at $37^{\circ} \mathrm{C}$ for $8 \mathrm{~h}$. As with the growth curve experiments, all cultures were found to be viable and NAG-thiazoline was not found to inhibit growth at concentrations as high as $1 \mathrm{mg} / \mathrm{ml}$.

\subsection{Morphological effect of NAG-thiazoline on $\mathrm{E}$. coli}

Bulgecin (a natural product comprised of a 4-O-sulfonyl-GlcNAc residue linked with a 4-hydroxy-5-(hydroxymethyl)-L-proline), in combination with sub-lethal concentrations of $\beta$-lactam antibiotics, has been shown to cause prominent bulges in the middle of elongated $E$. coli cells without being inhibitory to cell growth [9]. Subsequent in vitro studies indicated that the compound inhibits only the family $1 \mathrm{E}$. coli lytic transglycosylase, Slt70 at low concentrations [8,9] suggesting a specific role for this enzyme in the maintenance of cell shape and peptidoglycan metabolism. Given that this selective lytic transglycosylase inhibitor does not inhibit growth but rather affects the cell morphology of E. coli, cells grown in the presence and absence of NAG-thiazoline were prepared for examination by phase contrast microscopy. Cells grown at $37^{\circ} \mathrm{C}$ in $\mathrm{LB}$ broth for $3 \mathrm{~h}$ in the presence of $600 \mu \mathrm{g} / \mathrm{ml} \mathrm{NAG-thiazoline} \mathrm{displayed} \mathrm{an} \mathrm{unusual}$ rounded up or "stubby" morphology (Fig. 2). This change occurred in all cells. In contrast, cells treated 


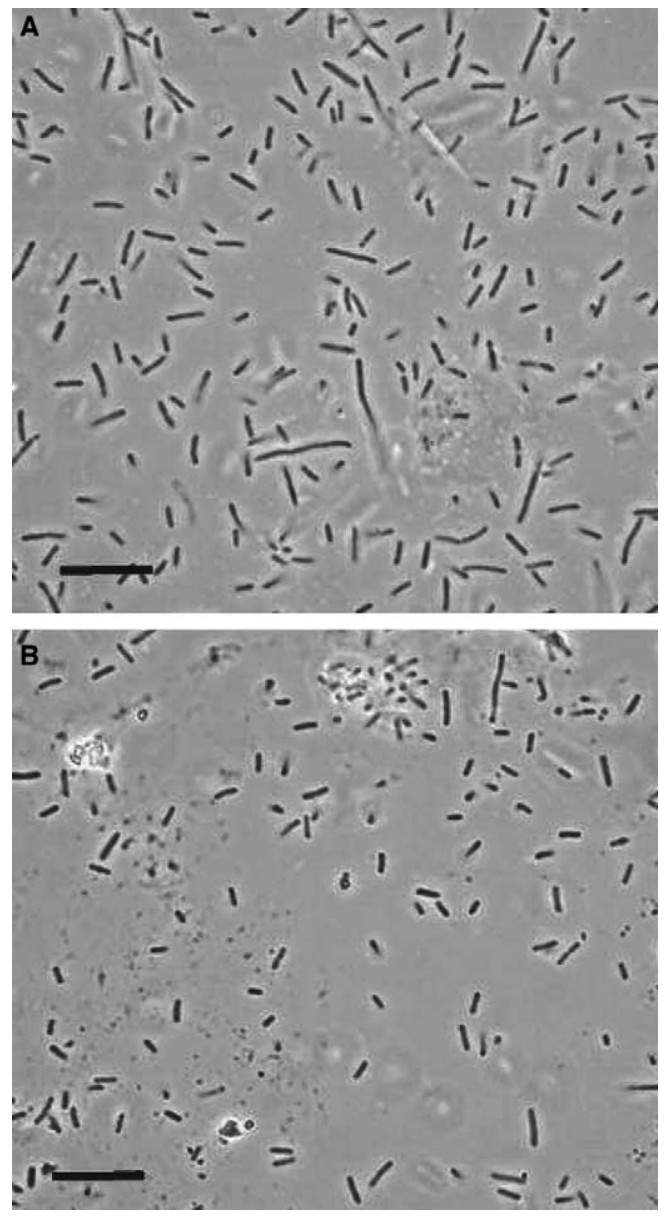

Fig. 2. Phase contrast micrographs of $E$. coli $\mathrm{DH} 5 \alpha$ cells grown in LB broth at $37^{\circ} \mathrm{C}$ and the (A) absence and (B) presence of $600 \mu \mathrm{g} / \mathrm{ml}$ NAG-thiazoline. Bar denotes $5 \mu \mathrm{m}$.

with equivalent concentrations of GlcNAc showed no such alteration in morphology. It should be noted that, unlike the situation with bulgecin, the observed change in cell morphology caused by NAG-thiazoline did not require the co-administration of sub-lethal quantities of $\beta$-lactams suggesting that, in this case, more than one type of LT may have been affected by exposure to NAG-thiazoline. Indeed, the non-lethal affect of NAGthiazoline on cell morphology is more analogous to the observations made with mutant strains of $E$. coli in which the genes of all six known membrane-bound lytic transglycosylases have been disrupted [3]. These deletion mutants showed growth in chains and were slightly coccoid in shape (viz., a reduction in cylindrical cell shape). However, while this interpretation is consistent with the observations, it is also conceivable that NAGthiazoline may inhibit a different class of enzyme associated with cell morphology.

Scanning electron microscopy (SEM) was used in an effort to provide both further details and a statistical analysis of the morphological changes to $E$. coli resulting from exposure to NAG-thiazoline. Initial experi- ments involved the examination of $E$. coli cells treated with $300 \mu \mathrm{g} / \mathrm{ml}$ NAG-thiazoline which showed only a $15 \%$ decrease in cell length compared to the control samples incubated in the absence of the compound(data not shown). However, it became apparent that the SEM images did not represent the entire cell population because the absolute total of treated cells observed in the SEM fields was considerably lower compared to that from control cultures. Thus, only a sub-population of the treated cells were fixed to the polycarbonate membranes negating the opportunity to observe and measure the smaller ones seen by phase microscopy.

\subsection{Analysis of cell surface properties}

The finding that the shorter, treated $E$. coli cells did not adhere to SEM grids suggested the surface properties of these cells was altered, likely as an indirect result of the morphological changes. A preliminary investigation of this possibility was conducted by analysing both the LPS profiles and cell surface hydrophobicities of the cells. The LPS profiles of cells grown in the presence of NAG-thiazoline, as judged by gel electrophoresis, were not significantly different to control cells (data not shown). This result was not unexpected given that $E$. coli $\mathrm{DH} 5 \alpha$ is a rough strain thus producing LPS molecules comprised of lipid A, core oligosaccharide, and no more than one O-chain subunit. However, the overall hydrophobicity of the cell surface was greatly influenced by growth in the presence of NAG-thiazoline. As indicated in Table 1, the surface of treated cells was clearly more hydrophilic in nature as very few cells partitioned into the organic solvent compared to those from control cultures. Moreover, this alteration in cell surface hydrophobicity appeared to be dependant on NAGthiazoline concentration. Similar alterations in cell surface hydrophobicity have been observed with different pathogenic bacteria following antibiotic treatments and can result in modified adhesion propensity and thereby their pathogenicity (e.g., [16] and references therein).

\subsection{Inhibition of penicillin-induced lysis by NAG-thiaz- oline}

Changes to bacterial cell morphology have to involve alterations, either directly or indirectly, to the metabo-

Table 1

Cell surface hydrophobicities of E. coli $\mathrm{DH} 5 \alpha$

\begin{tabular}{ll}
\hline Growth conditions & BATH $(\%)^{\mathrm{a}}$ \\
\hline Control & $31.1 \pm 2.76$ \\
$+100 \mu \mathrm{g} / \mathrm{ml}$ NAG thiazoline & $22.6 \pm 3.57$ \\
$+300 \mu \mathrm{g} / \mathrm{ml}$ NAG thiazoline & $9.64 \pm 0.772$ \\
$+600 \mu \mathrm{g} / \mathrm{ml}$ NAG thiazoline & $2.86 \pm 0.316$ \\
\hline
\end{tabular}

${ }^{\mathrm{a}} \operatorname{Mean} \pm \operatorname{SD}(n=3)$. 
lism of the rigid cell wall polymer peptidoglycan. NAGthiazoline has been used previously to investigate the reaction mechanism of a bacterial $\beta$-hexosaminidase $[12,13,17]$. NAG-thiazoline-lipid II hybrids have also been synthesized as potential inhibitors of transglycosylases involved in peptidoglycan biosynthesis [18]. Recent studies in our laboratory have shown NAG-thiazoline to be an inhibitor of the lytic transglycosylases [11]. Thus, the morphological changes accompanying the treatment of cells with NAG-thiazoline observed in this study may have resulted from the inhibition of one or more autolytic enzymes, including the lytic transglycosylases. This view was supported by observations that the co-administration of this compound with ampicillin prevented the cell autolysis that normally accompanies exposure to $\beta$ lactam antibiotics. As shown in Fig. 3, the addition of $1.7 \times$ MIC (viz. $5 \mu \mathrm{g} / \mathrm{ml}$ ) of ampicillin to growing cultures of $E$. coli resulted in both the cessation of growth and a time-dependent loss in turbidity consistent with the onset of autolysis. This lysis was confirmed by microscopic examination of the cultures. Inclusion of $300 \mu \mathrm{g} /$ $\mathrm{ml}$ NAG-thiazoline together with the $\beta$-lactam did not prevent the antibiotic-induced cessation of growth, but in contrast to the control cultures, these cells did not undergo autolysis. Moreover, the extremely elongated cell morphology that results from treatment of E. coli with ampicillin prior to their autolysis was not observed with cells co-treated with NAG-thiazoline (data not shown). Given these observations, together with the in vitro studies made with purified lytic transglycosylase [11], it is tempting to speculate that NAG-thiazoline inhibits the lytic transglycosylases that comprise the complexes responsible for the biosynthesis of peptidoglycan in the cylindrical regions of the sacculus. Clearly, however, more detailed studies will be required to support this view.

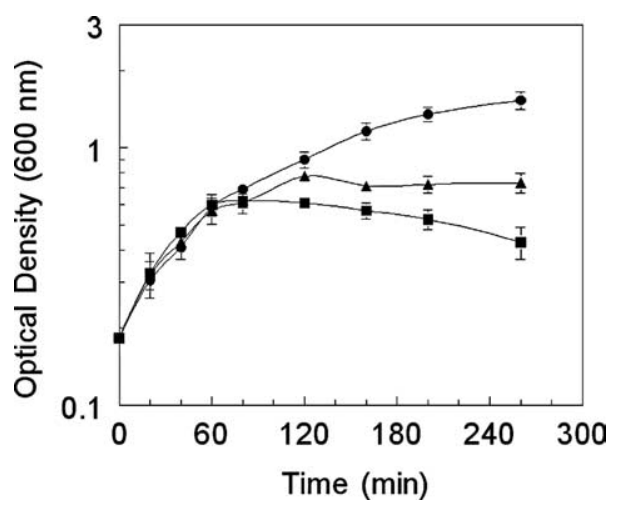

Fig. 3. Inhibition of ampicillin-induced lysis by NAG-thiazoline. Cultures of $E$. coli DH5 $\alpha$ were grown in LB broth at $37{ }^{\circ} \mathrm{C}$ to a cell density of $\mathrm{OD}_{600}$ of 0.18 (early exponential phase), divided into three aliquots, and then supplemented with () nothing (control), (অ) $5 \mu \mathrm{g} /$ $\mathrm{ml}(1.7 \times$ MIC) ampicillin, or $(\boldsymbol{\Delta}) 5 \mu \mathrm{g} / \mathrm{ml}$ ampicillin and $300 \mu \mathrm{g} / \mathrm{ml}$ NAG-thiazoline. The error bars denote standard deviation $(n=3)$.

\subsection{Concluding remarks}

By virtue of its unique chemical structure in nature and its importance to bacterial cell viability, the metabolism of peptidoglycan has been exploited as a target for antibacterial drug development (recently reviewed by Koch [19]). Unfortunately, some of the important antibiotics developed are quickly becoming irrelevant for clinical use as drug resistance levels increase in both human and animal pathogens. For example, the prevalence of $\beta$-lactamases among a variety of important pathogens has seriously compromised the general therapeutic use of the $\beta$-lactams (monobactams, penicillins, cephalosporins), compounds that are functional analogs of the stem peptide portion of the peptidoglycan-repeating unit. Using a different mode of resistance, vancomycin-resistance in enterococci (VRE) develops when alterations arise in the stem peptides of their peptidoglycan resulting in a decreased affinity for the antibiotic [20]. Despite these alarming trends, however, the peptidoglycan sacculus still contains other potential targets for drug development [21], including the lytic transglycosylases. The apparent ubiquity of these enzymes amongst the bacteria [7] further supports their usefulness as an antibacterial target. The ability of NAG-thiazoline to cause changes to the hydrophobicity of the E. coli cell surface, a factor associated with adherence of pathogens to host cells, together with the inhibition of peptidoglycan biosynthetic complexes responsible for cell morphology and autolysis demonstrated in this study provides further impetus to continue investigating the potential of the lytic transglycosylases as an alternative target for the development of a new class of antibiotics.

\section{Acknowledgements}

These studies were supported by an operating grant (MOP 49623) to AJC from the Canadian Institutes of Health Research and a post-graduate scholarship to NTB from the Natural Sciences and Engineering Research Council of Canada.

\section{References}

[1] Young, K.D. (2003) Bacterial shape. Mol. Microbiol. 49, 571-580.

[2] Shockman, G.D. and Höltje, J.-V. (1994) Microbial peptidoglycan (murein) hydrolases. In: Bacterial Cell Wall (Ghuysen, J.-M. and Hakenbeck, R., Eds.), pp. 131-166. Elsevier, Amsterdam, The Netherlands.

[3] Heidrich, C., Ursinus, A., Berger, J., Schwarz, H. and Höltje, J.-V. (2002) Effects of multiple deletions of murein hydrolases on viability, septum cleavage, and sensitivity to large toxic molecules in Escherichia coli. J. Bacteriol. 184, 6093-6099.

[4] Höltje, J.-V. (1998) Growth of the stress-bearing and shapedetermining murein sacculus of Escherichia coli. Microbiol. Mol. Biol. Rev. 62, 181-203. 
[5] Höltje, J.-V., Mirelmen, D., Sharon, N. and Schwarz, U. (1975) Novel type of murein transglycosylase in Escherichia coli. J. Bacteriol. 124, 1067-1076.

[6] Höltje, J.-V. and Tuomanen, E.I. (1991) The murein hydrolases of Escherichia coli: properties, functions and impact on the course of infections in vivo. J. Gen. Microbiol. 137, 441-454.

[7] Blackburn, N.T. and Clarke, A.J. (2001) Identification of four families of microbial lytic transglycosylases. J. Mol. Evol. 52, 78-84.

[8] Romeis, T., Vollmer, W. and Höltje, J.-V. (1993) Characterization of three different lytic transglycosylases from Escherichia coli. FEMS Microbiol. Lett. 111, 141-146.

[9] Templin, M.F., Edwards, D.H. and Höltje, J.-V. (1992) A murein hydrolase is the specific target of bulgecin in Escherichia coli. J. Biol. Chem. 267, 20039-20043.

[10] Thunnissen, A.-M.W.H., Roxeboom, H.J., Kalk, K.H. and Dijkstra, B.W. (1995) Structure of the $70-\mathrm{kDa}$ soluble lytic transglycosylase complexed with bulgecin A. Implications for the enzymatic mechanism. Biochemistry 34, 12729-12737.

[11] Reid, C.W., Blackburn, N.T. and Clarke, A.J. (2004). Inhibition of membrane-bound lytic transglycosylase B by NAG-thiazoline: Evidence for substrate-assisted catalysis. Biochemistry, submitted.

[12] Bovin, N.V., Zurabyan, S.E. and Khorlin, A.Y. (1981) Synthesis and study of thiazoline derivatives of D-glucose. Izv. Akad. Nauk. SSSR, Ser. Khim. 2, 441-443.

[13] Knapp, S., Vocadlo, D., Guo, Z., Kirk, B., Lou, J. and Withers, S.G. (1996) NAG-thiazoline, an $N$-acetyl- $\beta$-hexosaminidase inhibitor that implicates acetamido participation. J. Am. Chem. Soc. $118,6804-6805$.
[14] Paiment, A., Hocking, J. and Whitfield, C. (2002) Impact of phosphorylation of specific residues in the tyrosine autokinase, Wzc, on its activity in assembly of group 1 capsules in Escherichia coli. J. Bacteriol. 184, 6437-6447.

[15] Rosenberg, M., Gutnick, M. and Rosenberg, E. (1980) Adherence of bacteria to hydrocarbons: a simple method for measuring cellsurface hydrophobicity. FEMS Microbiol. Lett. 9, 29-33.

[16] Kustos, T., Kustos, I., Kilar, F., Rappai, G. and Kocsis, B. (2003) Effect of antibiotics on cell surface hydrophobicity of bacteria causing orthopedic wound infections. Chemotherapy 49, 237-242.

[17] Mark, B.L., Vocadlo, D.J., Knapp, S., Triggs-Raine, B.L., Withers, S.G. and James, M.N.G. (2001) Crystallographic evidence for substrate-assisted catalysis in a bacterial $\beta$-hexosaminidase J. Biol. Chem. 276, 10330-10337.

[18] Ritter, T.K. and Wong, C.-H. (2004) Synthesis of $N$-acetylglucosamine thiazoline/lipid II hybrids. Tetrahedron Lett. 42, 615618.

[19] Koch, A.L. (2003) Bacterial wall as target for attack: past, present, and future research. Clin. Microbiol. Rev. 16, 673-687.

[20] Bugg, T.D., Wright, G.D., Dutka-Malen, S., Arthur, M., Courvalin, P. and Walsh, C.T. (1991) Molecular basis for vancomycin resistance in Enterococcus faecium BM4147: biosynthesis of a depsipeptide peptidoglycan precursor by vancomycin resistance proteins VanH and VanA. Biochemistry 30, 10408-10415.

[21] Koch, A.L. (2000) Penicillin-binding proteins, beta-lactams, and lactamases: offensives, attacks, and defensive countermeasures. Crit. Rev. Microbiol. 26, 205-220. 